\title{
Tax aspects of mining companies in V4 countries
}

\author{
Jana SIMONIDESOV $A^{1}$, Zuzana KUDLOV $\check{A}^{2}$, Jozef LUKÁ $\check{C}^{3}$, Eva MANOV $\AA^{* 4}$ \\ and Katarína $\check{C} \boldsymbol{U} \mathbf{L K O V} \mathscr{A}^{5}$
}

Authors' affiliations and addresses:

${ }^{1}$ Faculty of Business Economics of the University of Economics in Bratislava with seat in Košice,

Tajovského 13, 04001 Košice, Slovakia

e-mail: jana.simonidesova@euba.sk

${ }^{2}$ Faculty of Business Economics of the University of Economics in Bratislava with seat in Košice,

Tajovského 13, 04001 Košice, Slovakia

e-mail: zuzana.kudlova@euba.sk

${ }^{3}$ Faculty of Business Economics of the University of Economics in Bratislava with seat in Košice,

Tajovského 13, 04001 Košice, Slovakia

e-mail: jozef.lukac@euba.sk

${ }^{4}$ Faculty of Business Economics of the University of Economics in Bratislava with seat in Košice, Tajovského 13, 04001 Košice,

Slovakia

e-mail: eva.manova@euba.sk

${ }^{5}$ Technical University in Košice, Faculty BERG, Letná 9, 04001 Košice, Slovakia

e-mail: katarina.culkova@tuke.sk

\section{*Correspondence:}

Eva Manová, University of Economics in Bratislava with seat in Košice, Tajovského 13, 04001 Košice, Slovakia

e-mail: eva.manova@euba.sk

\section{Acknowledgement:}

This paper is a partial output of the project of young researchers and doctoral students of the University of Economics in Bratislava no. I-21113-00, The use of financial analysis in examining the financial literacy of a selected group of the population.

How to cite this article:

Simonidesová, J., Kudlová, Z., Lukáč, J.,

Manová, E. and Čulková, K. (2021). Tax aspects

of mining companies in V4 countries. Acta

Montanistica Slovaca, Volume 26 (1), 35-46

DOI:

https://doi.org/10.46544/AMS.v26i1.03

\begin{abstract}
Presently there is no definite agreement of taxes definition. Most of the statistics include to tax incomes all obligatory fee of the public sector, which is not based on principles of equivalency. In this case, taxes can be defined as obligatory fees of the public sector, to which governments do not provide direct equal consideration. Modern tax systems are based on the taxation of incomes, consumption, and property. The trend in the area of EU countries taxation is a transition of the tax burden from incomes and capital to consumption. Mainly conditions of mining organisations are presented in the contribution when tax rates and trends in the area of income tax of mining organisations are described. The goal of the contribution is to describe the tax burden of business subjects (mining and extraction organisations) in Hungary, Slovakia, Poland, and the Czech Republic. In the contribution, we orientate the research to a detailed analysis of tax rates in chosen countries. The contribution consists of results conclusions, found by analysis, as well as by comparison of the tax burden of V4 business subjects. The result of the problem analysis presents suggestions of the tax mix change and transition to the relatively high tax burden of a job, mainly for low-income employees, to the lower tax burden of high taxes, as for example, environmental taxes. The results are useful for the management of mining organisations, which provide a possibility of financial savings. On the international level, the results serve for the comparing of the financial situation of mining organisations in V4 countries, which is suitable for a determination of raw material states policies.
\end{abstract}

\section{Keywords}

Tax burden, V4, mining and extraction organisation. 


\section{Introduction}

Taxation, tax system, tax burden present the characteristics that in any market economy belong between many times discussed expert themes from the view of experts, as well as from the view of publicity. The public sector in developed countries decides on the allocation of prevalent part of disposable sources of the society when problems of its financing belong to actual theoretical and practical solutions (Behun et al. 2018; Gavurova et al. 2017). In developed countries, tax incomes present more than $95 \%$ of all public incomes. Such incomes are also presented by the incomes of mining and extraction organisations activities.

The mining industry in most other countries pays special taxes for the use of community-owned in situ resources in addition to taxes levied on businesses in general. General taxes include the personal and corporate income tax, the GST, payroll, and transaction taxes. The additional tax, in most cases, is a form of royalty. Countries use tax incentives with aim of the investment. However, as for the tax using in the sectors, there is number of discussions that cannot be overlooked (Rosova et al., 2020). Mining sector from the view of tax incentives introduction is beneficial for the governments due to their special character, as for example the changing tax arrangements is more easy to make in comparing with investment to infrastructure. Therefore, tax incentives must be properly determined to bring demanded results.

The tax area (as well as the whole fiscal system) in mining sector have to provide the governments would achieve the profit from the raw material base of the state. This should consider the raw material base belong to the state, however, in case the raw materials are extracted, they bring profit for the single company and the society. Tax legislation, providing legal certainty and stability, contribute to the reduction of the financial risk and by this way they contribute to the increasing interest to invest to the sector (Bilan et al., 2017), together with transparent tax system together with double taxation avoiding avoiding. Through such tax system governments could create the effective environment to attract the investment to the sector, which would result in the supporting of the national economy as well.

Taxation in mining sector is moreover influenced by exploitation costs that in different countries can have varied elements. For example , Argentina Mining Investment Law created favourable environment to pay taxes from exploitation, providing taxes deduction. Australia allows written of some exploitation costs in case the mining organisation would satisfies certain criteria as set forth in the Taxation Act. Canada has a flexible, which create profitable tax system. In Canada for example the tax incentives are solved by provincial point of view. In Indonesia, exploitation cost can be reduced annually according to the contracts, capitalisation and amortisation. The other countries, for example Mexico, provide a taxpayer to reduct fees and expenses in periods before single exploitation, which could save the money for the mining company in long-term period. Mining companies in Tanzania could save the money from taxes due to the development of capital costs (Global Mining Industry (2012).

The importance of the problem results from the heavy dependence of V4 countries on the extractive industries. Consequences of the mining tax on the development of the mining industry, as well as the public revenue collection. Although several institutions and universities publish on the issue, data on mining tax remains difficult to access. Thus, improving the information in the mining area taxation has become a priority for the international community. The presented solving of the problem with taxation is not dealing in researches of the V4 countries; therefore, contribution provides removing of the research gap of the problem. To solve the problems with taxation could contribute to the management of mining organisations, promising financial savings and comparing the financial situation of mining organisations in V4 countries, which is suitable for the determination of raw material states policies.

The importance of solving taxation in the mining industry results from the present situation with Covid-19, when governments respond to the pandemic situation. This situation has economic impacts to the mining industry, when coronavirus influenced the health of mining workers and business partners of mining companies. This caused financial problems of the mining sectors, where tax incentives should be supporting the economy of mining companies. In this heavy situation, poor taxation policy could deepen the existing economic and financial problems of the mining companies (Swart, 2020).

The problem of the tax burden of the mines in the world is becoming a popular area. Research of Otto (1998) shows that due to the changes in the area of mining, there is decreasing of entering obstacles and lower risk of entering new areas of mining, and by this way, increasing of investments is registered in majority of countries. In the last years, the Australian government fought and lost an intensive and very public fight with the mining industry in the country after the establishment of a new tax of profit (Bell, 2013). The government made a resolution that the establishment of a new tax could threaten investments, employment, and growth. Due to the mentioned, the government dropped the tax. Also, March (2014) criticised this measurement, speaking of governmental failure in effective enforcement of tax from mining, which should help the business. Results of the elimination of tax from mining are described by Westmore (2014), mentioning that voting of elimination of mining tax brought improving relations with mining organisations and state institutions, which presented one of the promises of government in 2013. 
Legislative frame, determining taxes for mining organisations in developing countries, which go through a rapid trend of sources development, is many times relatively modern and adequate. Research of Guj (2013) presents a practical view of analysis and improvement of the administrative frame and systems for authorship honorarium and other taxes, specific for mining, as for example, license fee. According to Lilford (2020) license fees can be applied according to various bases, either according to the volume, value in various value chains or profit in various jurisdictions.

Research of Finér (2017) helps to solve some limitations that are given to tax researchers due to the significant concealing of tax affairs of mining organisations. Results of the research speak of the present trend to avoid tax obligation, which is too orientated to legal income tax rates, in spite of presently tax minimising is relying on concrete tax stimulus and other gaps in the tax legislation of individual countries.

Results of analysis of the social, tax, and environmental information published from south African mining companies, are presented by Villiers (2014).

Three arguments are many times mentioned to support higher taxes from mining, which are according to Tilton (2004) insufficient, since wealth, connected with especially rich deposits, belongs to inhabitants of the country; mining organisations should compensate the state and the society by raw material using in regard to the real value, which results from not the renewable character of the sources; division of the wealth, presented by mining, is unrighteous. Too much value is giving to mining organisations and too little value for a host country to support economic development. In this sense tax and levy burden of mining activities should be changed.

The contribution of Sikka (2010) presents information, how mining organisations promise responsible behaviour but avoiding tax and tax obligation evasion in the countries. A number of authors try to eliminate tax evasion. Experimental results show the method suggested by Tian (2016) significantly increases the effectiveness of tax evasion detection and offers a clear explanation of tax evasion behaviour in a group of mining organisations.

The worldwide trend shows presently three types of taxes in the area of mining (Mitchell, 2009):

- Turnover tax (depending on the type of extracted raw material).

- Income and profit tax - removing of part from the mining organisation profit after elimination of all costs, including turnover tax. After profit taxation, costs are on the side of the businessman, which is different on the side of turnover tax. Income tax is usually higher than turnover tax, regularly around $30-50 \%$ and more. The highest-taxed profits from mining are in Norway (90\%) and Great Britain (75\%). The income tax increased to $40 \%$ in Australia in 2010.

- The tax of excessive profits belongs to such mining organisations with over average profit in the mining sector.

Presently in conditions of the Slovak Republic, there is no other approach to taxation of mining organisation, only according to the Law No 595/2003 Z. z. - Law of income tax. Incomes in any country are regularly taxed by income tax. In the case of the exclusive responsibility of member states, the EU does not have a direct influence on the tax collection or exact determination of rates for individual taxes. Through tax rate decrees EU provides for member states a certain expansion of tax rates when the minimal and maximal level of the tax rate is determined. The government of a given country decides on the tax level and its collection.

\section{Material and Methods}

The base of the problem research presents available legislative measurements. Here belongs Law No 595/2003 Z.z. - Law of income tax is as amended before. Similarly, the research results from the database of financial reports of Slovakian mining organisations. We analysed the level of the tax burden in chosen mining organisations, making business in the mining sector. It should be added that the article presented by us contains not only an analysis of mining companies but also an analysis of the entire economy from the point of view of income tax.

The goal of the research is to make an analysis of tax burden from the view of income tax in comparing V4 countries. The subject of comparison is made according to the choice of chosen Slovakian mining organisations from the view of direct taxes, mainly income tax during 2009-2019. To meet the main goal, basic general logic methods had been used. In addition to general methods of analysis, synthesis, comparison, induction, deduction, analogy, graphical representation and selection, we will also use the above-sophisticated methods in the article. Above all, it will be a statistical testing of the relationships between the variables from the point of view of the Pearson and Spearman correlation coefficient, on the basis of which we will try to define the significance of the relationships between tax inducers. Another method is the method of parametric and non-parametric testing of the statistical significance of differences between selected tax indicators of the V4 countries. Analysed sample presents a selection of the most known mining companies from the view of achieved income tax. According to the economic structure SK NACE (Statistical classification of economic activities in Slovakia), selected companies in the mining sector deal with the following activities:

- Mining of coal and lignite; 
- Mining of limestone;

- Mining of dolomite;

- Mining of natural sands;

- Mining of gravel;

- Mining of logs - pebbles;

- Mining of broken stones.

\section{Results}

Mining organisations are taxed according to available decrees, and Slovakia does not have any special tax on mining organisations. We analysed tax burden in V4 comparing in the following period from the view of the development of income tax rates, direct taxes, income taxes of legal and physical entities.

\section{Analysis of tax burden in V4 countries}

Tax quota - the rate of taxes on GDP - presents one of the most used aggregate indicators of the tax burden. Following tables 1 illustrates the development of tax quota in individual V4 countries.

Tab. 1 Income tax-direct taxes in V4 in 2005 - 2017 in \% GDP

\begin{tabular}{|c|c|c|c|c|}
\hline $\begin{array}{c}\text { Slovak } \\
\text { Republic }\end{array}$ & $\begin{array}{c}\text { Income tax } \\
\text { of physical } \\
\text { entities }\end{array}$ & $\begin{array}{c}\text { Income tax of } \\
\text { legal entities }\end{array}$ & $\begin{array}{c}\text { Other } \\
\text { direct } \\
\text { taxes }\end{array}$ & $\begin{array}{c}\text { Direct } \\
\text { taxes } \\
\text { together }\end{array}$ \\
\hline 2005 & 3,0 & 2,7 & 0,6 & $\mathbf{6 , 3}$ \\
\hline 2006 & 2,9 & 2,8 & 0,6 & $\mathbf{6 , 4}$ \\
\hline 2007 & 2,9 & 2,9 & 0,6 & $\mathbf{6 , 4}$ \\
\hline 2008 & 3,1 & 3,0 & 0,6 & $\mathbf{6 , 7}$ \\
\hline 2009 & 2,8 & 2,5 & 0,6 & $\mathbf{5 , 8}$ \\
\hline 2010 & 2,6 & 2,5 & 0,5 & $\mathbf{5 , 6}$ \\
\hline 2011 & 2,8 & 2,4 & 0,5 & $\mathbf{5 , 7}$ \\
\hline 2012 & 2,9 & 2,4 & 0,5 & $\mathbf{5 , 8}$ \\
\hline 2013 & 2,9 & 2,9 & 0,6 & $\mathbf{6 , 4}$ \\
\hline 2014 & 3,0 & 3,3 & 0,6 & $\mathbf{6 , 8}$ \\
\hline 2015 & 3,1 & 3,7 & 0,5 & $\mathbf{7 , 3}$ \\
\hline 2016 & 3,3 & 3,5 & 0,5 & $\mathbf{7 , 3}$ \\
\hline 2017 & 3,4 & 3,5 & 0,5 & $\mathbf{7 , 4}$ \\
\hline
\end{tabular}

\begin{tabular}{|c|c|c|c|c|}
\hline $\begin{array}{l}\text { Czech } \\
\text { Republic }\end{array}$ & $\begin{array}{c}\text { Income tax } \\
\text { of physical } \\
\text { entities }\end{array}$ & $\begin{array}{l}\text { Income tax of } \\
\text { legal entities }\end{array}$ & $\begin{array}{l}\text { Other } \\
\text { direct } \\
\text { taxes }\end{array}$ & $\begin{array}{c}\text { Direct } \\
\text { taxes } \\
\text { together }\end{array}$ \\
\hline 2005 & 4,2 & 4,1 & 0,2 & 8,6 \\
\hline 2006 & 3,9 & 4,4 & 0,3 & 8,6 \\
\hline 2007 & 4,1 & 4,5 & 0,3 & 8,8 \\
\hline 2008 & 3,5 & 4,0 & 0,3 & 7,8 \\
\hline 2009 & 3,4 & 3,4 & 0,3 & 7,1 \\
\hline 2010 & 3,3 & 3,2 & 0,3 & 6,8 \\
\hline 2011 & 3,5 & 3,2 & 0,3 & 7,0 \\
\hline 2012 & 3,6 & 3,1 & 0,3 & 7,0 \\
\hline 2013 & 3,7 & 3,2 & 0,3 & 7,2 \\
\hline 2014 & 3,7 & 3,3 & 0,2 & 7,3 \\
\hline 2015 & 3,6 & 3,4 & 0,2 & 7,2 \\
\hline 2016 & 3,8 & 3,5 & 0,2 & 7,6 \\
\hline 2017 & 4,0 & 3,5 & 0,2 & 7,7 \\
\hline
\end{tabular}




\begin{tabular}{|c|c|c|c|c|}
\hline Hungary & $\begin{array}{l}\text { Income tax } \\
\text { of physical } \\
\text { entities }\end{array}$ & $\begin{array}{l}\text { Income tax of } \\
\text { legal entities }\end{array}$ & $\begin{array}{l}\text { Other } \\
\text { direct } \\
\text { taxes }\end{array}$ & $\begin{array}{c}\text { Direct } \\
\text { taxes } \\
\text { together }\end{array}$ \\
\hline 2005 & 6.4 & 2.1 & 0.3 & 8.8 \\
\hline 2006 & 6.6 & 2.3 & 0.3 & 9.2 \\
\hline 2007 & 7.1 & 2.7 & 0.3 & 10.1 \\
\hline 2008 & 7.5 & 2.6 & 0.3 & 10.3 \\
\hline 2009 & 7.2 & 2.1 & 0.4 & 9.7 \\
\hline 2010 & 6.4 & 1.1 & 0.3 & 7.8 \\
\hline 2011 & 4.8 & 1.1 & 0.3 & 6.3 \\
\hline 2012 & 5.3 & 1.3 & 0.3 & 6.8 \\
\hline 2013 & 5.0 & 1.2 & 0.4 & 6.6 \\
\hline 2014 & 4.9 & 1.5 & 0.4 & 6.8 \\
\hline 2015 & 4.9 & 1.7 & 0.4 & 7.0 \\
\hline 2016 & 4.9 & 2.2 & 0.4 & 7.5 \\
\hline 2017 & 5.1 & 1.9 & 0.4 & 7.4 \\
\hline
\end{tabular}

\begin{tabular}{|c|c|c|c|c|}
\hline Poland & $\begin{array}{c}\text { Income tax } \\
\text { of physical } \\
\text { entities }\end{array}$ & $\begin{array}{c}\text { Income tax of } \\
\text { legal entities }\end{array}$ & $\begin{array}{c}\text { Other } \\
\text { direct } \\
\text { taxes }\end{array}$ & $\begin{array}{c}\text { Direct } \\
\text { taxes } \\
\text { together }\end{array}$ \\
\hline 2005 & 4.3 & 2.1 & 0.5 & $\mathbf{6 . 9}$ \\
\hline 2006 & 4.6 & 2.4 & 0.4 & $\mathbf{7 . 4}$ \\
\hline 2007 & 5.2 & 2.7 & 0.4 & $\mathbf{8 . 3}$ \\
\hline 2008 & 5.3 & 2.7 & 0.4 & $\mathbf{8 . 4}$ \\
\hline 2009 & 4.5 & 2.2 & 0.4 & $\mathbf{7 . 2}$ \\
\hline 2010 & 4.3 & 1.9 & 0.4 & $\mathbf{6 . 7}$ \\
\hline 2011 & 4.3 & 2.0 & 0.4 & $\mathbf{6 . 7}$ \\
\hline 2012 & 4.5 & 2.1 & 0.4 & $\mathbf{7 . 0}$ \\
\hline 2013 & 4.5 & 1.8 & 0.5 & $\mathbf{6 . 7}$ \\
\hline 2014 & 4.6 & 1.7 & 0.5 & $\mathbf{6 . 8}$ \\
\hline 2015 & 4.7 & 1.8 & 0.4 & $\mathbf{6 . 9}$ \\
\hline 2016 & 4.8 & 7.1 & 0.4 & $\mathbf{7 . 4}$ \\
\hline 2017 & 5.0 & & & \\
\hline
\end{tabular}

From $1^{\text {st }}$ January 2004, Law of income tax is applicable in Slovakia. Taxation according to the Law is applicable also for mining organisations. From the entry of the Law to the end of 2012, the income tax rate for businessmen and other taxpayers was $19 \%$. From $1^{\text {st }}$ January 2013, the tax rate increased to $23 \%$. From $1^{\text {st }}$ January 2014 , the rate for legal entities decreased to $22 \%$. The next change was in 2017 , when the tax rate decreased again, to $21 \%$.

From $1^{\text {st }}$ January 2020, significant change is made by the government of Slovakia, approving the novelisation of the income tax law. It presents novelisation, bringing changes to Slovakian legislation due to the incorporation of the EU decree (so-called ADAT2 decree). The decree deals with imbalances during the different evaluations of taxpayers and financial tools in EU countries, etc.

According to the opinion of novelisation proposers of the income tax law, such decreasing in the tax rate would enable the more effective collection of taxes and speed up Slovakian economic growth. At the same time, decreasing tax rate could enable support of new investments inflow and the possibility of businessmen to realise business at an increasing level.

In the area of direct taxes in the Czech Republic, in recent years, income from taxes of self-employed persons prevail over incomes from taxes of legal entities. In 2005 tax incomes from direct taxes presented 8,6\% GDP. In 2017 it was only 7,7\%. In previous years, the structure of direct taxes had yet a lower percentage of tax incomes.

Direct taxes in Hungary present over 7\% GDP, while the highest representation belongs to income tax from self-employed persons. Income taxes from legal entities present a very low rate on GDP against income taxes from self-employed persons. In 2017 it presented only 1,9\% against 5,1\% from physical entities. The mentioned situation results from the decreasing and establishment of tax rates for small businessmen.

Direct taxes in Poland present over 7\% GDP, and according to the data from Eurostat, taxes from selfemployed persons have the highest representation on the incomes from taxes. Income tax for self-employed persons is increasing from 2013, while income tax for legal entities is moving around 1,8\% GDP. Other direct taxes do not have a significant trend of the change.

Taxes are the most important tool of fiscal policy of the state, by which the state realises its intentions. Mainly due to the mentioned level of tax burden and tax mix present the most important part of the environment, in which the state and the society can realise their goals. A comparison of direct taxes development in V4 is given in Figure 1. 


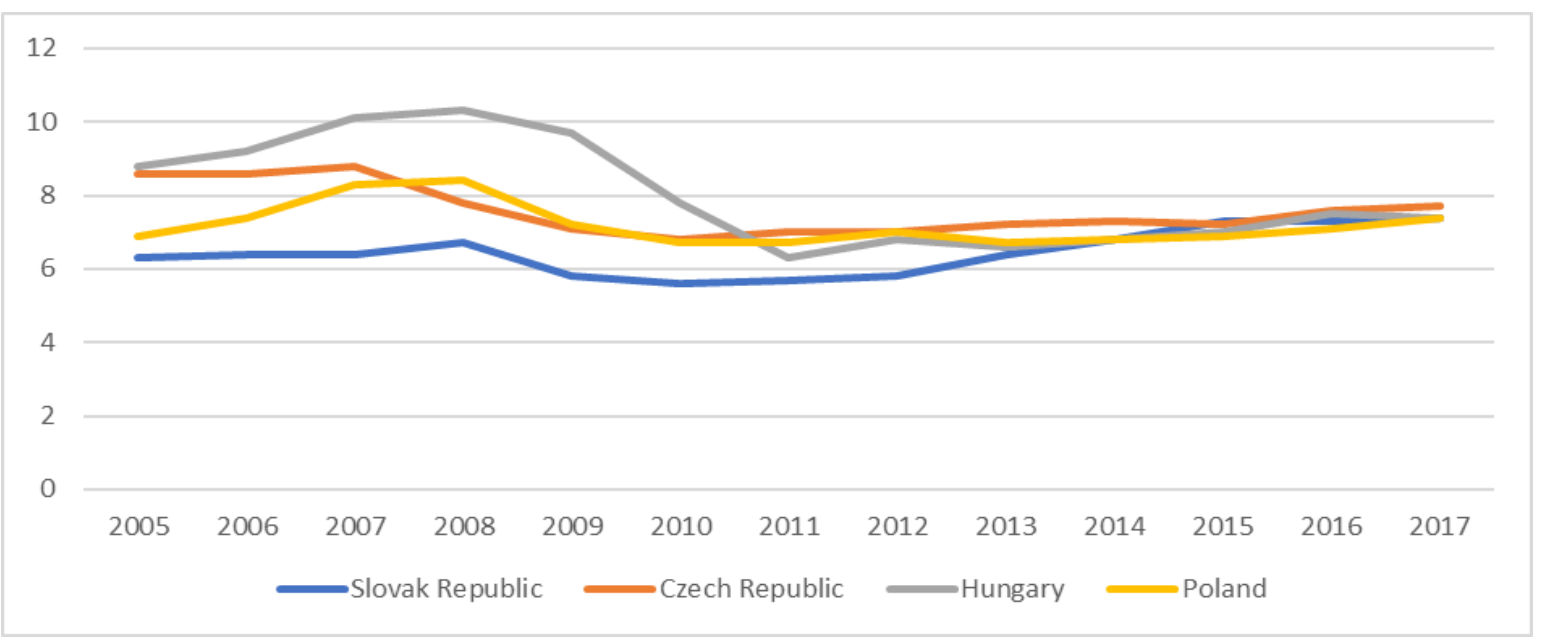

Fig. 1. Development of direct taxes rate in V4 in 2005 - 2017 in \% GDP Source: own processing according to Intrastat

The rate of direct taxes on GDP in individual V4 countries had at the beginning of the analysed period a very different structure on GDP. In recent years, the level of direct taxes in individual V4 countries has visibly the same trend - the rate of direct taxes in all V4 countries is moving around 7-8 \% GDP. The highest rate of direct taxes on GDP is in the Czech Republic, and the lowest rate of direct taxes on GDP is recorded in Poland. But the recorded differences are not very significant.

In the following section, we will try to identify whether there is a relationship between individual tax indicators in countries in terms of correlation relationships: the Spearmen and Pearson correlation coefficient.

Tab. 2 Correlation between the indicator of direct tax

\begin{tabular}{|c|c|c|c|c|c|}
\hline Variable & & Direct taxes SK & Direct taxes CZ & Direct taxes HU & Direct taxes PL \\
\hline \multirow[t]{4}{*}{ 1. Direct taxes together SK } & Pearson's r & - & & & \\
\hline & p-value & - & & & \\
\hline & Spearman's rho & 一 & & & \\
\hline & $\mathrm{p}$-value & - & & & \\
\hline \multirow[t]{4}{*}{ 2. Direct taxes together $\mathrm{CZ}$} & Pearson's r & 0.257 & - & & \\
\hline & $\mathrm{p}$-value & 0.397 & - & & \\
\hline & Spearman's rho & 0.509 & - & & \\
\hline & p-value & 0.076 & - & & \\
\hline \multirow[t]{4}{*}{ 3. Direct taxes together $\mathrm{HU}$} & Pearson's r & -0.074 & 0.634 & - & \\
\hline & $\mathrm{p}$-value & 0.810 & 0.020 & - & \\
\hline & Spearman's rho & 0.026 & 0.573 & - & \\
\hline & $\mathrm{p}$-value & 0.932 & 0.041 & - & \\
\hline \multirow[t]{4}{*}{ 4. Direct taxes together PL } & Pearson's r & 0.222 & 0.593 & 0.795 & - \\
\hline & $\mathrm{p}$-value & 0.466 & 0.033 & 0.001 & - \\
\hline & Spearman's rho & 0.406 & 0.675 & 0.757 & - \\
\hline & $\mathrm{p}$-value & 0.168 & 0.011 & 0.003 & - \\
\hline
\end{tabular}

Based on the results, the compared indicators reach the values of correlation indicators at a low level mostly direct weak dependence. In one case, the dependence is expressed by a minus value, which means that in the case of the pair direct tax SR and direct tax HU, there is a weak indirect dependence, which, however, borders on the value 0 . 


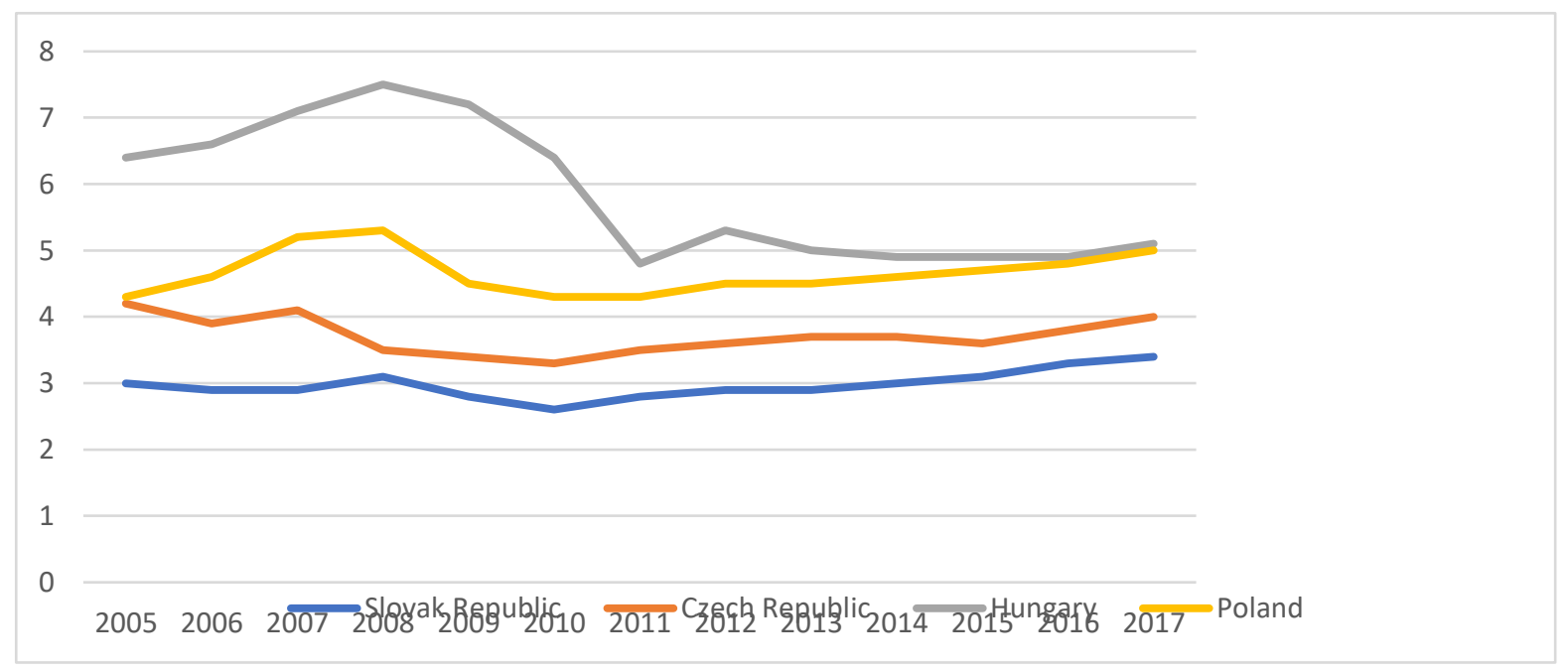

Fig. 2. Development of income tax rate for self-employed persons in V4 in \% GDP Source: own processing according to Intrastat

The highest rate on GDP belongs to income tax of self-employed persons in Hungary and Poland, in spite of in Poland income tax of self-employed persons presents progressive tax and real income tax amendment for selfemployed persons enable numbers of tax relief, such as in case of insurance payment, part of incomes from social security and several other preferences. Tax relief covers expenses on education, health care, and habitation.

Tab. 3 Correlation between the indicator of income tax of physical entities

\begin{tabular}{|c|c|c|c|c|c|}
\hline Variable & & $\begin{array}{c}\text { Income tax of physical } \\
\text { entities SK }\end{array}$ & $\begin{array}{c}\text { Income tax of physical } \\
\text { entities } \mathrm{CZ}\end{array}$ & $\begin{array}{c}\text { Income tax of physical } \\
\text { entities HU }\end{array}$ & $\begin{array}{c}\text { Income tax of physical } \\
\text { entities PL }\end{array}$ \\
\hline \multirow[t]{4}{*}{$\begin{array}{l}\text { 1. Income tax of physical } \\
\text { entities SK }\end{array}$} & Pearson's r & - & & & \\
\hline & p-value & - & & & \\
\hline & $\begin{array}{l}\text { Spearman's } \\
\text { rho }\end{array}$ & - & & & \\
\hline & p-value & - & & & \\
\hline \multirow[t]{4}{*}{$\begin{array}{l}\text { 2. Income tax of physical } \\
\text { entities CZ }\end{array}$} & Pearson's r & 0.479 & - & & \\
\hline & p-value & 0.097 & - & & \\
\hline & $\begin{array}{l}\text { Spearman's } \\
\text { rho }\end{array}$ & 0.506 & - & & \\
\hline & $\mathrm{p}$-value & 0.078 & - & & \\
\hline \multirow[t]{4}{*}{$\begin{array}{l}\text { 3. Income tax of physical } \\
\text { entities HU }\end{array}$} & Pearson's r & -0.325 & 0.003 & 一 & \\
\hline & p-value & 0.278 & 0.993 & - & \\
\hline & $\begin{array}{l}\text { Spearman's } \\
\text { rho }\end{array}$ & -0.196 & -0.028 & - & \\
\hline & p-value & 0.521 & 0.928 & - & \\
\hline \multirow[t]{4}{*}{$\begin{array}{l}\text { 4. Income tax of physical } \\
\text { entities PL }\end{array}$} & Pearson's r & 0.567 & 0.265 & 0.321 & 一 \\
\hline & $\mathrm{p}$-value & 0.043 & 0.381 & 0.285 & - \\
\hline & $\begin{array}{l}\text { Spearman's } \\
\text { rho }\end{array}$ & 0.677 & 0.303 & 0.227 & - \\
\hline & p-value & 0.011 & 0.314 & 0.456 & - \\
\hline
\end{tabular}

We also examined the relationships between variables in income tax of physical entities using correlation coefficients. We found that in most pairs of relationships, there is a direct mean linear dependence. The exception is the relationship between the variables for the country, the Slovak Republic and Hungary, where we can again observe the indirect medium dependence. 


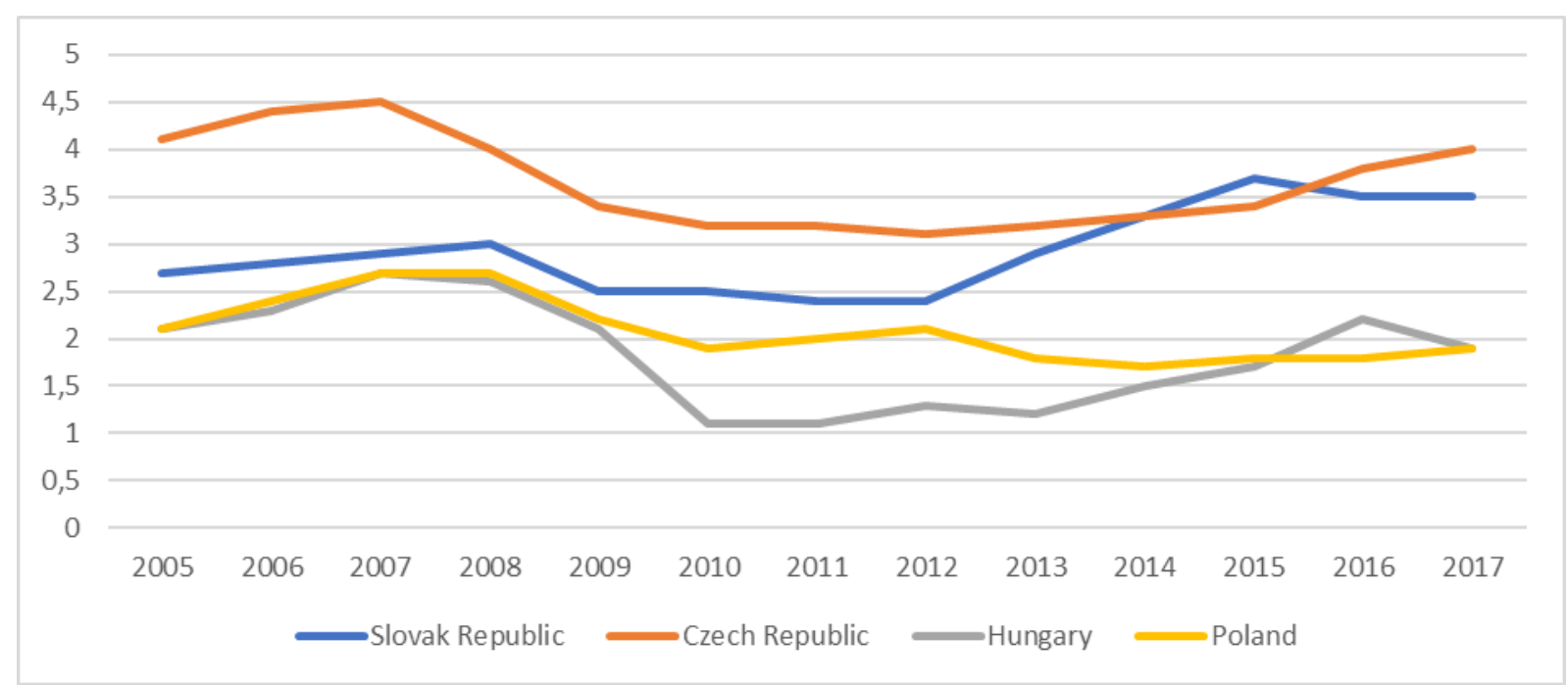

Fig. 3. Development of income tax rate from legal entities in V4 in $2005-2017$ in \% GDP Source: own processing according to Intrastat

Income tax from legal entities in comparing with V4 countries has the highest rate in Slovakia. Therefore, its rate on GDP belongs among the highest rates in the last years of the analysed period. The lowest rate of income tax from legal entities on GDP is recorded in Hungary due to the unification of the tax rate in 2017 for legal entities to a common level $-9 \%$, which presents the lowest rate in the EU.

The last indicator in which we examined the dependence of variables is the indicator of income tax of legal entities. The results suggest that again, we do not see dependence between the values of countries in this area. The relationship between the variables is negative according to the Spearman and Pearson coefficients indicating an indirect mean dependence. Other relationships have a moderate direct dependence. However, for the pair Hungary and the Czech Republic, the dependence is strong because the value of the coefficient is more than 0.8 .

Tab. 4 Correlation between the indicator of income tax of legal entities

\begin{tabular}{|c|c|c|c|c|c|}
\hline Variable & & $\begin{array}{c}\text { Income tax of legal } \\
\text { entities SK }\end{array}$ & $\begin{array}{c}\text { Income tax of legal } \\
\text { entities } \mathrm{CZ}\end{array}$ & $\begin{array}{c}\text { Income tax of legal } \\
\text { entities HU }\end{array}$ & $\begin{array}{c}\text { Income tax of legal } \\
\text { entities PL }\end{array}$ \\
\hline \multirow{4}{*}{$\begin{array}{l}\text { 1. Income tax of legal } \\
\text { entities SK }\end{array}$} & Pearson's r & - & & & \\
\hline & $\mathrm{p}$-value & - & & & \\
\hline & $\begin{array}{l}\text { Spearman's } \\
\text { rho }\end{array}$ & - & & & \\
\hline & p-value & - & & & \\
\hline \multirow[t]{4}{*}{$\begin{array}{l}\text { 2. Income tax of legal } \\
\text { entities } C Z\end{array}$} & Pearson's r & 0.058 & - & & \\
\hline & p-value & 0.850 & - & & \\
\hline & $\begin{array}{l}\text { Spearman's } \\
\text { rho }\end{array}$ & 0.386 & - & & \\
\hline & p-value & 0.193 & - & & \\
\hline \multirow[t]{4}{*}{$\begin{array}{l}\text { 3. Income tax of legal } \\
\text { entities HU }\end{array}$} & Pearson's r & 0.274 & 0.848 & - & \\
\hline & p-value & 0.365 & $<.001$ & - & \\
\hline & $\begin{array}{l}\text { Spearman's } \\
\text { rho }\end{array}$ & 0.367 & 0.907 & - & \\
\hline & p-value & 0.217 & $<.001$ & - & \\
\hline \multirow[t]{4}{*}{$\begin{array}{l}\text { 4. Income tax of legal } \\
\text { entities PL }\end{array}$} & Pearson's r & -0.321 & 0.763 & 0.719 & - \\
\hline & p-value & 0.285 & 0.002 & 0.006 & - \\
\hline & $\begin{array}{l}\text { Spearman's } \\
\text { rho }\end{array}$ & -0.421 & 0.519 & 0.595 & - \\
\hline & p-value & 0.152 & 0.069 & 0.032 & - \\
\hline
\end{tabular}

Source: own processing

The following section deals with testing the statistical significance of differences between the values of tax indicators. As the normality of variables is not tested, we used both parametric and non-parametric tests. In the ttest and wilcoson test, we test the agreement of two average values of indicators between successive years ( 3 
pairs for each analysed indicator) at the level of significance $\alpha(0.05)$ and determine the following hypotheses of the test:

$\mathrm{H}_{0}$ : there are no statistically significant differences between the values of the indicator between countries.

$\mathrm{H}_{1}$ : there are statistically significant differences between the values of the indicator between countries.

Tab. 5 Paired Samples T-Test

\begin{tabular}{|c|c|c|c|c|}
\hline Measure 1 & Measure 2 & Test & Statistic df & $\mathbf{p}$ \\
\hline \multirow{2}{*}{\multicolumn{2}{|c|}{ Income tax of physical entities SK - Income tax of physical entities CZ }} & Student & -10.50612 & $<.001$ \\
\hline & & Wilcoxon & 0.000 & 0.002 \\
\hline \multirow{2}{*}{\multicolumn{2}{|c|}{ Income tax of physical entities SK - Income tax of physical entities HU }} & Student & $\begin{array}{ll}-9.302 & 12\end{array}$ & $<.001$ \\
\hline & & Wilcoxon & 0.000 & 0.002 \\
\hline \multirow{2}{*}{\multicolumn{2}{|c|}{ Income tax of physical entities SK - Income tax of physical entities PL }} & Student & -22.21712 & $<.001$ \\
\hline & & Wilcoxon & 0.000 & 0.002 \\
\hline \multirow[t]{2}{*}{ Income tax of legal entities SK } & - Income tax of legal entities CZ & Student & -3.78912 & 0.003 \\
\hline & & Wil & 1.500 & 0.009 \\
\hline \multirow[t]{2}{*}{ Income tax of legal entities SK } & - Income tax of legal entities HU & Student & 6.49112 & $<.001$ \\
\hline & & Wilcoxon & 91.000 & 0.002 \\
\hline \multirow[t]{2}{*}{ Income tax of legal entities SK } & - Income tax of legal entities PL & Student & 4.78812 & $<.001$ \\
\hline & & Wilcoxon & 91.000 & 0.002 \\
\hline \multirow[t]{2}{*}{ Direct taxes together SK } & - Direct taxes together CZ & Student & -5.16112 & $<.001$ \\
\hline & & Wil & 1.000 & 0.002 \\
\hline \multirow[t]{2}{*}{ Direct taxes together SK } & - Direct taxes together HU & Student & $\begin{array}{lll}-3.560 & 12\end{array}$ & 0.004 \\
\hline & & Wilcoxon & 3.000 & 0.009 \\
\hline \multirow[t]{2}{*}{ Direct taxes together SK } & - Direct taxes together PL & Student & -3.57112 & 0.004 \\
\hline & & Wilcoxon & 4.000 & 0.011 \\
\hline
\end{tabular}

Source: own processing

By comparing the value of Sig. (p-value) from the previous table with the specified level of significance $\alpha$ $(0.001)$, we can state that for all indicators of tax of countries, the p-value is higher than the specified level of significance in a pair of income tax of legal entities SK - CZ, Direct tax SK - HU and Direct tax SK - PL. We can state that the difference between the values of indicators between the individual countries is statistically significant because the $p$-value is higher than $\alpha(0.001)$. We do not reject hypothesis $\mathrm{H}_{0}$. We accept hypothesis $\mathrm{H}_{1}$ for other pairs, which states that there is no statistically confirmed relationship between the variables of tax indicators.

\section{Income tax of mining organisations in Slovakia}

The tax burden of mines in Slovakia is not a searched area, but worldwide it becomes a real theme. We analysed income taxes in the mining sector in Slovakia in the analysed period 2009 - 2019, when comparing eight chosen Slovakian mines.

Tab. 6 Income tax of chosen mining organisations in Slovakia in 2009 - 2019

\begin{tabular}{|c|c|c|c|c|c|c|c|c|}
\hline & $\begin{array}{c}\text { Kameňolom } \\
\text { Sokolec } \\
\text { s.r.o. }\end{array}$ & $\begin{array}{c}\text { Štrkopiesky } \\
\text { Batizovce, } \\
\text { s.r.o. }\end{array}$ & KAS, a.s. & $\begin{array}{c}\text { SMZ, s.s. } \\
\text { Jelšava }\end{array}$ & $\begin{array}{c}\text { Kremnická } \\
\text { banská } \\
\text { spoločnost', } \\
\text { s.r.o. }\end{array}$ & $\begin{array}{c}\text { KSR - } \\
\text { Kameňolom } \\
\text { y SR, s.r.o. }\end{array}$ & Rudné bane & $\begin{array}{c}\text { Hornonitria } \\
\text { nske bane } \\
\text { Prievidza, } \\
\text { a.s. } \\
\end{array}$ \\
\hline 2009 & 132415 & 85124 & $\begin{array}{l}\text { Not reporting } \\
\text { the tax }\end{array}$ & 1500000 & 35121 & 154460 & $\begin{array}{l}\text { Not reporting } \\
\text { the tax }\end{array}$ & 0 \\
\hline 2010 & 132415 & 79948 & $\begin{array}{l}\text { Not reporting } \\
\text { the tax }\end{array}$ & $\begin{array}{l}\text { Not reporting } \\
\text { the tax }\end{array}$ & 225516 & 154456 & $\begin{array}{l}\text { Not reporting } \\
\text { the tax }\end{array}$ & 0 \\
\hline 2011 & 123297 & 82248 & 52032 & $\begin{array}{l}\text { Not reporting } \\
\text { the tax }\end{array}$ & 172020 & 7009 & $\begin{array}{l}\text { Not reporting } \\
\text { the tax }\end{array}$ & 1921 \\
\hline 2012 & 86836 & 90692 & -281276 & $\begin{array}{c}\text { Not reporting } \\
\text { the tax }\end{array}$ & 51461 & -178502 & $\begin{array}{l}\text { Not reporting } \\
\text { the tax }\end{array}$ & 65687 \\
\hline 2013 & 65923 & -2337 & -133686 & 1600000 & 121147 & -178502 & 20009 & 6427 \\
\hline 2014 & 58160 & -95419 & -28848 & 1300000 & 25322 & -474369 & 37242 & 3600 \\
\hline 2015 & 41756 & -20172 & 247232 & 1400000 & 123043 & 189873 & 3957 & 68440 \\
\hline 2016 & 123300 & 139276 & 108122 & 959925 & 12215 & 572746 & 5471 & 303704 \\
\hline 2017 & 123100 & -27995 & 212329 & 2000000 & 59635 & 191112 & 11636 & 2104 \\
\hline 2018 & 119484 & $\begin{array}{l}\text { Not reporting } \\
\text { the tax }\end{array}$ & -562 & 2500000 & -41 & 191112 & 55 & -1124 \\
\hline 2019 & 119420 & $\begin{array}{l}\text { Not reporting } \\
\text { the tax }\end{array}$ & $\begin{array}{l}\text { Not reporting } \\
\text { the tax }\end{array}$ & 1800000 & 58481 & 73750 & 21956 & 382 \\
\hline
\end{tabular}




\section{Source: own processing according to FinStat}

The income tax is different in any analysed mining organisation. Table 2 evaluates the highest rate of income tax is in SMZ, a.s. Jelšava, when recorded in 2018 till 2.5 mils. Eur. Opposite, in 2014 KSR Kameňolomy SR, s.r.o. achieved negative income tax at level -474 369 Eur. In other mining organisations, the tax had in analysed period variable trend. Several mining organisations did not have available all data for the analysed period. In a number of mining and extraction organisations, we can see that during the analysed period in several years, the tax was not reported. We assume it could be the consequence of the terminated activity or liquidation of the mining activity or the whole organisation.

The establishment of new modern technologies for the mining and processing of raw materials increases the job effectiveness considerably, contributing to the mining sector development. Figure 4 illustrates income tax development in individual Slovakian mines. As illustrated, the highest income tax is in SMZ, a.s. Jelšava.

\section{Discussion}

Taxes of mining and extraction organisations belong to the tax mix. Taxes of mining are considerably influencing the financial structure of mining companies (Škulánová, 2020). Unfortunately, mining companies mostly evade taxes. However, Ya'u et al. (2020) show a positive and significant relationship between taxes of mining companies and penalty. Therefore, companies must consider tax payment.

From the analysis results, the tax mix in Slovakia is considerably different from the average composition in the EU. While the tax burden is equally arranged among levies and direct and indirect taxes in the European Union, we can state there is obviously prevailingly high tax duty in Slovakia. Mentioned is applied in all compared V4 countries. The volume of income tax rate and property on GDP is also similar in all V4 countries. But Hungary collects in comparing with other V4 countries much more taxes from production and capital.

The rate of the tax burden of economic factors in Slovakia is not different from the tax burden in other V4 countries. Hungary has a lower burden on the job and more burden on consumption, as resulting from the analysis. We can conclude from the analysis of the rate of income tax from the job on whole tax and levy incomes in Slovakia is comparable with the Czech Republic and Poland. In the V4 group, only Poland is different from the view of taxes from the job, when the employees pay relatively higher payments compared to employers.

The income tax of legal entities in Slovakia presents the pillar of the tax burden of the capital. The highest rate of the tax is collected in the Czech Republic. Poland and Hungary collect income tax from legal entities, a lower rate of total incomes from capital taxes. However, Poland and Hungary have higher tax burden on property. For example, the tax on real estate in Poland presents over one-fifth of the incomes. Hungary and Poland, in comparison with Slovakia and the Czech Republic, have a much higher burden on capital due to the other taxes.

In the frame of tax analysis of mining organisations, the volume of the business should be considered, influencing mainly income tax rate and a legal form of the business (Afrizal et al., 2020). A lower corporate tax rate results in a larger reduction in the effective tax burden facing large businesses. (Freebairn, 2017). The decision of the taxes implications mostly in the capital-intensive mining industry is presently a challenging decision (van Wyk, 2016). Proper determination of tax policy in the mining organisation could contribute this way to the sustainability of the mining industry (Cruz et al., 2020).

\section{Conclusion}

Source of incomes to state budget present a number of taxes, but almost half of all incomes present valueadded tax (VAT). The second highest collected tax belongs to income tax from legal entities, followed by consumption taxes. Incomes from other taxes are similarly low. Tax from real estate is generally, for example, considering as the least tax, hindering economic growth. International institutions (European Commission, OEC, ICF) recommend Slovakia should change in long-time tax mix and move the high tax burden of job, mainly for low incomes employees, to lower taxes, such as tax from real estate, consumption taxes from alcohol or environmental taxes.

In the frame of economic factors, Slovakia has a higher tax burden on the job, which is similarly comparable with other V4 and EU countries. From the available data, there is obvious that more than half of total tax incomes are generated from the taxation of job. The tax rate also increased in 2009-2012 due to the legislative measurements. On the other side, the rate of incomes from consumption taxation has a decreasing trend. Taxation of capital causes the lowest rate on total incomes from taxes and levies. The rate of the tax burden of economic factors in Slovakia is not very different from the tax burden in other V4 countries. The future research and ambition of the authors is to evaluate the development of taxation in other industrial sectors, as well as to compare the results with the mining industry. 
Based on the statistical methods performed by us, we can state that there is no demonstrable relationship between selected tax indicators of the V4 countries.

\section{Summary}

Problems of tax burden present vast area, resulting from a big number of legislative decrees and laws. The tax burden of business subjects can be researched from the view of various aspects. The contribution is orientated to the comparison of the tax burden in V4 countries in the analysed period, orientated mostly to the different tax mix and often changes in tax legislation in V4 countries, either on the side of individual governments or on the side of EU (acceptance of obligatory decrees to national legislation), as well as their complete impacts to the level of the tax burden in the given countries. The presented contribution is orientated to the analysis of the tax environment in V4 countries. Similarly, we analysed chosen mining and extraction organisations from the view of income tax. In a number of worldwide countries, taxation of the mining and extraction organisations is managed by individual legal amendments and higher tax rates are accepted for the mining sector. In this way, there is also a higher tax burden and higher levy duties. In conditions of Slovakia, presently, there are no similar measurements.

\section{References}

Afrizal, D., Putra, W.E., Yuliusman, A., Hernando, R. The effect of accounting conservatism, CSR disclosure and tax avoidance on earnings management: Some evidence form listed companies in Indonesia. International Journal of Advanced Science and Technology, 2020, 29(4), 1441-1456.

Babčák, V. Daňové právo na Slovensku. 1. vyd. Bratislava: Epos, 2015. 752 s. ISBN 978-80-5620-091-9.

Behun M., Gavurova B., Tkacova A., Kotaskova A. (2018). The impact of the manufacturing industry on the economic cycle of European Union Countries. Journal of Competitiveness, 10 (1), 23-39. https://doi.org/10.7441/joc.2018.01.02

Bilan, Y., Gavurova, B., Stanislaw, G., Tkacova, A. (2017). The Composite Coincident Indicator (CCI) for Business Cycles. Acta Polytechnica Hungarica, 14(7), 71-90. DOI: 10.12700/APH.14.7.2017.7.5

Bell, S.; Hindmoor, A. (2014). The structural power of business and the power of ideas: The strange case of the Australian mining tax. New Political Economy, 2014, 19.3: 470-486. https://doi.org/10.1080/13563467.2013.796452

Burák, E. Daňovníctvo - daňová teória, daňová politika a daňové riziká. 1. vyd. Trenčín: Inštitút aplikovaného manažmentu, 2016. 203 s. ISBN 978-80-89600-26-7.

Cruz, T.L., Matlaba, V.J., Mota, J.A., de Oliveira, J.C., dos Santos, J.F., da Cruz, L.N., Neto, E.N.D. Assessing sustainability in mining industry: Social license to operate and other economic and social indicators in Canaa dos Carajás (Pará Brazil) (book chapter). World Sustainability Series, 2020, 555-573.

De Villiers, C. Low, M. Samkin, G.. The institutionalisation of mining company sustainability disclosures. Journal of Cleaner Production, 2014, 84: 51-58. DOI: 10.1016/j.jclepro.2014.01.089

Finér, L. Ylönen, M. Tax-driven wealth chains: A multiple case study of tax avoidance in the Finnish mining sector. Critical Perspectives on Accounting, 2017, 48: 53-81. https://doi.org/10.1016/j.cpa.2017.01.002

Freebairn, J. Comparison of a lower corporate income tax rate for small and large businesses. e-Journal of Tax Research, 2017, 15(1), 4-21.

Gavurova, B., Soltes, M., Kovac, M. (2017). Application of Cluster Analysis in Process of Competitiveness Modelling of Slovak Republic Regions. Transformations in Business \& Economics, 16(3), 129-147. DOI: 10.15240/tul/001/2019-2-008

Global Mining Industry, 2012: Corporate income taxes, mining royalties and other mining taxes A summary of rates and rules in selected countries. Available at: www.pwc.com/gx/mining

Guj, P., et al. How to improve mining tax administration and collection frameworks: A sourcebook. 2013. http://hdl.handle.net/10986/16700

Lilford, E.; Guj, P. Different Types of Mineral Royalties. Mining Taxation. Springer, Cham. p. 43-69. https://doi.org/10.1007/978-3-030-49821-4

Marsh, D.; Lewis, Ch.; Chesters, J. The Australian mining tax and the political power of business. Australian Journal of Political Science, 2014, 49.4: 711-725. https://doi.org/10.1080/10361146.2014.954985

Mitchell, P. Taxation and investment issues in mining. Advancing the EITI in the Mining Sector: A Consultation with Stakeholders, Extractive Industries Transparency Initiative, Oslo, 2009, 27-31.

Nerudová, D. Daňová politika v Evropské unii.1. vyd. Praha: Wolters Kluwer ČR, 2017. 213 s. ISBN 978-807552-682-3.

Otto, J. M. Global changes in mining laws, agreements and tax systems. Resources policy, 1998, 24.2: 79-86. 
Rosova, A., Behun, M., Khouri, S., Cehlar, M., Ferencz, V., Sofranko, M. (2020). Case study: the simulation modeling to improve the efficiency and performance of production process. Wireless Networks. DOI: $10.1007 / \mathrm{s} 11276-020-02341-\mathrm{z}$

Rožňák, P. Mechanismy fungování Evropské unie: In quorum gratiam ? 1. vyd. Ostrava: Key Publishing s.r.o., 2015. 331 s. ISBN 978-80-7418-237-2.

Schultzova, A. Daňovníctvo: daňová teória a politika I. 2. vyd. Bratislava: Wolters Kluwer, 2015. 308 s. ISBN 978-80-7478-867-3.

Sikka, P. Smoke and mirrors: Corporate social responsibility and tax avoidance. Accounting forum. No longer published by Elsevier, 2010. p. 153-168. https://doi.org/10.1016/j.accfor.2010.05.002

Smolik, J. Úvod do studia mezinárodních vztahũ. 1. vyd. Praha: Grada Publishing, a.s., 2014. 232 s. ISBN 97880-247-5131-3.

Swart, A. Understanding the sector impact of COVID-19. Mining and Metals, 2020, 1-2.

Škulánová, N. Impact of selected determinants on the financial structure of the mining companies in the selected countries. Review of Economic Perspectives, 2020, 2(1), 197-215.

Štrkolec, M. Zabezpečovacie inštitúty pri správe daní.1. vyd. Košice: Univerzita Pavla Jozefa Šafárika v Košiciach, 2017. 163 s. ISBN 978-80-8152-537-7.

Tian, F., et al. Mining suspicious tax evasion groups in big data. IEEE Transactions on Knowledge and Data Engineering, 2016, 28.10: 2651-2664. https://doi.org/10.1109/TKDE.2016.2571686

Tilton, J. E. Determining the optimal tax on mining. Natural Resources Forum. Oxford, UK: Blackwell Publishing Ltd., 2004. p. 144-149. https://doi.org/10.1111/j.1477-8947.2004.00081.x

Wyk, F., Vlok, P.J., Jin, M., Khojandi, A., Brunke, N.: Incorporating business risks in physical asset replacement: A case in the mining industry. Proceedings of the 2016 Industrial and Systems Engineering Research Conference ISERC, 2016, 1980-1985.

Velichová, L. Didaktika daňovníctva - teória a prax.1.vyd. Bratislava: Ekonóm, 2018. 128 s. ISBN 978-80-2254538-9.

Westmore, P., et al. National affairs: Mining tax repeal puts government back on track. News Weekly, 2014, 2932: 4.

Ya'u, A., Saad, N., Mas'ud, A. Effects of economic deterrence variables and royalty rates on petroleum profit tax compliance in Nigeria: an empirical analysis. International Journal of Energy Sector Management, 2020, 14(6), 1275-1296. https://doi.org/10.1108/IJESM-12-2019-0011

Daňové zákony Česko. Daňová legislativa pro profesionály v paralelním znění (2014/2015/2016) s komentářem zmén. 1.vyd. Bratislava: DonauMedia, 2016. 441 s. ISBN 978-80-89364-89-3.

Daňové zákony Česko. 1.vyd. Bratislava: DonauMedia, 2016. 168 s. ISBN 978-80-89364-87-9.

Daňové zákony XXL Profi Česko. 1. vyd. Bratislava: DonauMedia, 2016. 168 s. ISBN 978-80-89364-88-6.

Finančná správa SR.2021. Retrieved January 16, 2021 from https://finstat.sk/databaza-financnych-udajov

Eurostat, 2021. Retrieved 16th January, 2021 from https://ec.europa.eu/eurostat/data/database 